\title{
Erratum to: Reliability of the ADI-R for the Single Case-Part II: Clinical Versus Statistical Significance
}

Domenic V. Cicchetti - Catherine Lord •

Kathy Koenig • Ami Klin · Fred R. Volkmar

Published online: 26 November 2014

(c) Springer Science+Business Media New York 2014

Erratum to: J Autism Dev Disord (2014) 44:3154-3160

DOI 10.1007/s10803-014-2177-8

In the original publication of the article, Eq. 1 was published incorrectly and the correct equation is as follows:

$\mathrm{Z}=(\mathrm{PO}-\mathrm{PC}) / \mathrm{SEM}$

The online version of the original article can be found under doi:10.1007/s10803-014-2177-8.

D. V. Cicchetti $(\bowtie) \cdot$ K. Koenig · F. R. Volkmar

Child Study Center, Yale University School of Medicine,

New Haven, CT, USA

e-mail: dom.cicchetti@yale.edu

D. V. Cicchetti

Yale Home Office, North Branford, CT 06471, USA

C. Lord

Cornell Medical College/NY Presbyterian Hospital, Columbia

University, New York, NY, USA
A. Klin
Emory University, Atlanta, GA, USA 